4 Wessels VF, Junge-Hülsing G, Losse H. Untersuchungen zur Natriumpermeabilität der Erythrozyten bei Hypertonikern und Normotonikern mit familiärer Hochdruckbelastung. Zeitschrift für Kreislaufforschung 1967; $56: 374-80$.

5 Postnov YV, Orlov SN, Shevchenkoa A, Adler AM. Altered sodium permeability, calcium binding and Na-K-ATPase activity in the red blood cell membrane in essential hypertension. Pfluegers Arch 1977; $371: 263-9$.

${ }^{6}$ Garay RP, Meyer P. A new test showing abnormal net $\mathrm{Na}^{+}$and $\mathrm{K}^{+}$fluxes in erythrocytes of essential hypertensive patients. Lancet $1979 ; \mathrm{i}: 349-53$.

7 Henningsen NC, Mattsson S, Nosslin B, Nelson D, Ohlsson O. Abnormal whole body and cellular (erythrocytes) turnover of ${ }^{22} \mathrm{Na}^{+}$in normotensive relatives of probands with essential hypertension. Clin Sci 1979;57 : $321-4$ s.

8 Edmondson RPS, Thomas RD, Hilton PJ, Patrick J, Jones NF. Abnormal leucocyte composition and sodium transport in essential hypertension. Lancet 1975 ; : $: 1003-5$.

9 Poston L, Sewell RB, Wilkinson SP, et al. Evidence for a circulating sodium transport inhibitor in essential hypertension. $\mathrm{Br}$ Med f 1981; 282:847-9.

10 de Wardener HE, MacGregor GA. Further observations on Dahl's hypothesis that a saluretic substance may be responsible for a sustained rise in arterial pressure. Its possible role in essential hypertension. Kidnet Int 1980;18:1-9.

11 Dunn MJ, Tannen RL. Low renin hypertension. Kidney Int 1974;5:31725 .
12 Laragh JH, Letcher RL, Pickering TG. Renin profiling for diagnosis and treatment of hypertension. $7 A M A 1979 ; 241: 151-6$

${ }^{13}$ Schalekamp MA, Beevers DG, Kolsters G, Lebel M, Fraser R, Birkenhäger WH. Body-fluid volume in low renin hypertension. Lancet 1974; ii: $310-1$.

14 Hilton PJ. Sodium and potassium flux rates in normal leucocytes in an artificial extracellular fluid. Clin Sci $1973 ; 44: 439-45$

15 Roulston JE, MacGregor GA. Measurement of plasma renin activity by radioimmunoassay after prolonged cold storage. Clin Chim Acta 1979; 88:45-8.

16 Dusterdieck G, McElwee G. Estimation of angiotensin II concentration in human plasma by radioimmunoassay. Some applications to physiological and clinical states. Euro $\mathcal{F}$ Clin Invest $1971 ; 2: 32-8$.

17 Jones JC, Carter GD, MacGregor GA. Interference by polar metabolites in a direct radioimmunoassay for plasma aldosterone. Ann Clin Biochem $1981 ; 18: 54-9$.

${ }^{18}$ Dahl LK, Knudsen KD, Iwai J. Humoral transmission of hypertension: evidence from parabiosis. Circ Res $1969 ; 24$, suppl: 21 -33.

19 Haddy FJ, Overbeck HW. The role of humoral agents in volume expanded hypertension. Life Sci 1976;19:935-48.

20 Blaustein MP. Sodium ions, calcium ions, blood pressure regulation, and hypertension: a reassessment and a hypothesis. Am f Physiol 1977; 232(3):C165-73.

(Accepted 12 February 1981)

\title{
Is your enema really necessary?
}

\author{
MONA L ROMNEY, H GORDON
}

\section{Abstract}

Two hundred and seventy-four women admitted for delivery of singleton infants were studied for the effects of a preparatory enema on faecal contamination, duration of labour, and the incidence of infection in the newborn. Altogether 149 of the women were given an enema (controls) and 125 were not.

The two groups showed no significant difference in the degree of faecal contamination during the first and second stages of labour, and the incidences of gross contamination were similar. Contamination after an enema was especially difficult to control, since it was more likely to be fluid. Seven neonates in each group showed evidence of infection, bowel organisms being isolated from four in the no-enema group and two in the control group. Durations of labour, though not strictly comparable, were similar in the two groups.

The findings suggest that when preparing for normal labour the enema should be reserved for women who have not had their bowels open in the past 24 hours and have an obviously loaded rectum on initial pelvic examination.

\section{Introduction}

In a recent study ${ }^{1}$ we looked at the value of shaving the pubic area of women admitted to the delivery suite in labour. Having established that shaving was not beneficial to the patient, we decided to examine other midwifery procedures.

Division of Obstetrics and Gynaecology, Northwick Park Hospital and Clinical Research Centre, Harrow, Middlesex

MONA L ROMNEY, SRN, SCM, research sister

H GORDON, FRCS ED, FRCOG, consultant obstetrician and gynaecologist
It has long been established practice in many midwifery units to administer an enema to all patients in labour. This is claimed to have three major benefits. An empty bowel facilitates the descent of the presenting part, reduces faecal contamination, and reflexly stimulates uterine activity. We have tried to establish the truth of these claims.

\section{Pre-existing attitudes}

MEDICAL STAFF

With only two exceptions, the medical staff of the unit of all grades (senior house officer to consultant) thought that the lack of an enema could delay the descent of the presenting part, complicate labour, and lead to unacceptable faecal contamination, especially in the second stage.

\section{MIDWIVES}

The midwives were also united in their attitude. Most objected strongly to managing patients in labour unless an enema had been given and the bowel emptied. They thought that without an emena labour would be prolonged and the incidence of instrumental delivery increased. They foresaw faecal contamination of the baby and thought that offensive odour would embarrass both staff and patients.

\section{PATIENTS}

One hundred and twenty antenatal patients were interviewed. Thirty-six were primigravid, had never had an enema, and were unable to comment. They were, however, willing to accept whatever professional advice they were given. The remaining 84 parous patients were divided in their opinions. Forty-two considered the procedure degrading and uncomfortable but accepted it as the price of a "clean delivery." The others thought that they should be offered some choice, and several mentioned suppositories as an acceptable alternative. 
One hundred and five postpartum patients were then interviewed. Six found the procedure disturbing and frightening. All six had been in strong labour at the time of the enema and described how frightened they had been in the toilet when attempting to defecate. They had been unable to distinguish between uterine contractions and bowel cramps related to the enema and thought they were about to deliver their babies into the toilet. In contrast, 30 patients liked the enema and regarded it as an important preparation for labour. The remaining 69 patients accepted the enema as necessary but found it unpleasant.

\section{Methods}

Initial hostility from staff made it difficult to design an effective protocol for the trial. Two consultants agreed to participate, but the design of the pilot trial represented a somewhat unsatisfactory compromise.

Two groups of patients were studied. Eighty-four consecutive patients were admitted in early labour at term. Only women with singleton pregnancies were included, and all were at the 37th week or more at the onset of labour. No enema was given to these patients. A control group consisted of 111 patients at or beyond term admitted direct to the delivery suite for induction of labour. Indications for induction were weight loss at term, prolonged pregnancy, or minimal hypertension at term. Only singleton pregnancies were studied. Induction was by artificial rupture of the membranes and infusion of

\section{Results}

PILOT STUDY

In the first stage of labour 84 of the 100 patients not given an enema had no contamination. Of the 124 women who had been given an enema, 104 (also $84 \%$ ) were clean. In the second stage 61 of the 100 untreated patients remained clean compared with $80(65 \%)$ of the controls. This difference was not significant.

\section{RANDOMISED CONTROLLED STUDY}

Fifty patients were studied, and 25 received an enema. In the first stage 24 of the 25 untreated women remained clean compared with 21 of the treated controls. In the second stage 19 of the no-enema group remained clean compared with 21 of the controls. The differences were not significant.

\section{COMBINED SERIES}

Table I gives the results of the pilot and randomised studies combined. In both the untreated and control groups the increase in contamination in the second stage was largely related to grade 1 (minimal) contamination. The incidence of gross contamination (grade

TABLE I-Incidence of faecal contamination in labour. Combined series

\begin{tabular}{|c|c|c|c|c|c|c|c|}
\hline & \multirow{3}{*}{$\begin{array}{c}\% \text { of women } \\
\text { with no } \\
\text { contamination }\end{array}$} & \multirow{3}{*}{$\begin{array}{l}\text { No of women } \\
\text { with no } \\
\text { contamination }\end{array}$} & \multicolumn{4}{|c|}{ Women with contamination } & \multirow{3}{*}{$\underset{\text { total }}{\text { Grand }}$} \\
\hline & & & \multicolumn{3}{|c|}{ No with grade: } & \multirow{2}{*}{ Total } & \\
\hline & & & 1 & 2 & 3 & & \\
\hline 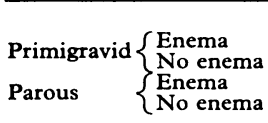 & $\begin{array}{l}84 \\
83 \\
84 \\
89\end{array}$ & $\left.\begin{array}{l}\text { First stage } \\
51 \\
44 \\
74 \\
64\end{array}\right\} 138$ & $\begin{array}{r}7 \\
6 \\
10 \\
6\end{array}$ & $\begin{array}{l}1 \\
1 \\
3 \\
1\end{array}$ & $\begin{array}{l}2 \\
2 \\
1 \\
1\end{array}$ & $\left.\begin{array}{r}10 \\
9 \\
14 \\
8\end{array}\right\} 22$ & $\left.\begin{array}{l}61 \\
53 \\
88 \\
72\end{array}\right\} 114$ \\
\hline$\left\{\begin{array}{l}\text { Enema } \\
\text { No enema }\end{array}\right.$ & $\begin{array}{l}84 \\
86\end{array}$ & $\left.\begin{array}{l}125 \\
108\end{array}\right\} 233$ & $\begin{array}{l}17 \\
12\end{array}$ & $\begin{array}{l}4 \\
2\end{array}$ & $\begin{array}{l}3 \\
3\end{array}$ & $\left.\begin{array}{l}24 \\
17\end{array}\right\} 41$ & $\left.\begin{array}{l}149 \\
125\end{array}\right\} 274$ \\
\hline 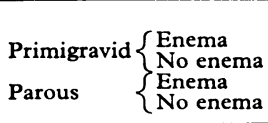 & $\begin{array}{l}67 \\
66 \\
66 \\
58\end{array}$ & 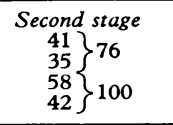 & $\begin{array}{l}14 \\
11 \\
17 \\
19\end{array}$ & $\begin{array}{l}3 \\
2 \\
9 \\
7\end{array}$ & $\begin{array}{l}3 \\
5 \\
4 \\
4\end{array}$ & $\left.\begin{array}{l}20 \\
18 \\
30 \\
30\end{array}\right\} 60$ & $\left.\begin{array}{l}61 \\
53 \\
88 \\
72\end{array}\right\} 114$ \\
\hline$\left\{\begin{array}{l}\text { Enema } \\
\text { No enema }\end{array}\right.$ & $\begin{array}{l}66 \\
62\end{array}$ & $\left.\begin{array}{l}99 \\
77\end{array}\right\} 176$ & $\begin{array}{l}31 \\
30\end{array}$ & $\begin{array}{r}12 \\
9\end{array}$ & $\begin{array}{l}7 \\
9\end{array}$ & $\left.\begin{array}{l}50 \\
48\end{array}\right\} 98$ & $\left.\begin{array}{l}149 \\
125\end{array}\right\} 274$ \\
\hline
\end{tabular}

Significance of differences between untreated and control groups: first stage $\chi^{2}=0 \cdot 17, p>0 \cdot 5$; second stage $x^{2}=0.62, p>0 \cdot 4$. (Student's $t$ test.)

oxytocin. These patients had a routine enema before induction. In addition, 13 patients in the study (no-enema) group insisted on an enema and were included in the controls. Sixteen patients in the control group refused an enema and were therefore included in the study group. Thus 100 patients had no enema (84 spontaneous labour, 16 induced) and 124 had an enema (111 induced labour, 13 spontaneous labour). Twelve other patients (eight study, four control) were initially entered into the trial but required caesarean section and were eliminated from the final analysis.

Once the pilot study had been completed it became possible to obtain agreement for a randomised study. Patients selected were in spontaneous labour with a mature (greater than 37 weeks') fetus. They were allocated to enema and no-enema groups according to whether the last digit of the hospital case number was odd (enema group) or even (no-enema group). After 50 cases it became clear that the midwives and to some extent the patients were drawing their own conclusions and it was becoming difficult to adhere to the agreed protocol. The trial was therefore concluded.

The enema was a low-volume, disposable, phosphate enema (Fletcher's Disposable Phosphate Enema) containing sodium acid phosphate $B P 10 \% \mathrm{w} / \mathrm{v}$ and sodium phosphate $P h$ Eur $8 \% \mathrm{w} / \mathrm{v}$.

Assessment of results-The results in terms of faecal contamination were assessed on an arbitrary four-point scale: 0 , clean (no contamination); 1, minimal faecal soiling but no formed motion or appreciable diarrhoea; 2, not more than two formed motions or episodes of diarrhoea; 3, frequent formed or fluid motions. We also considered the duration of labour and the incidence of infection in both mother and baby.
3) was strikingly similar in both groups. The midwives conducting the deliveries noted that where contamination occurred, women who had been given an enema were more likely to have fluid contamination, which was especially difficult to control.

\section{DURATION OF LABOUR}

Because we included patients in whom labour was induced comparison of duration of labour was not strictly valid. Nevertheless, there were similar patterns of labour in the two groups (table II), suggesting that an enema did not significantly influence the duration. The similar durations of labour in the two groups also eliminated any bias in the incidence of either contamination or infection, which could in theory be associated with duration of labour.

\section{INFECTION}

All the patterns were closely monitored for evidence of infection in either mother or baby. Where infection occurred, each case was discussed with the cross-infection sister and the microbiologist to decide if the infection could have been related to faecal contamination at the time of delivery.

One mother suffered an extensive infection of her episiotomy. Swabs showed a heavy growth of Escherichia coli. This mother had grade 3 faecal contamination during the second stage despite having . 
had an enema, and probably this was related to her subsequent infection. Seven babies in each group showed evidence of infection. Table III shows the site of each positive swab together with the infecting organism and degree of faecal contamination. There was no significant difference in the incidence of infection between the two groups. Bowel organisms were isolated from four infections in the no-enema group (cases 1-4) and from two in the control group (cases 8 and 9).

TABLE II-Durations of labour in untreated (no enema) and control (enema) groups of mothers (combined series)

\begin{tabular}{|c|c|c|c|c|c|c|c|c|}
\hline & & \multicolumn{6}{|c|}{ Duration of labour (hours) } & \multirow{2}{*}{ Tota } \\
\hline & & $\leqslant 4$ & -6 & -8 & -10 & -12 & $>12$ & \\
\hline \multicolumn{9}{|c|}{ No enema } \\
\hline $\begin{array}{l}\text { Primiparae } \\
\text { Multiparae }\end{array}$ & $\ldots$ & $\begin{array}{l}14 \\
36\end{array}$ & $\begin{array}{l}12 \\
11\end{array}$ & $\begin{array}{l}7 \\
7\end{array}$ & $\begin{array}{r}9 \\
15\end{array}$ & $\begin{array}{l}5 \\
2\end{array}$ & $\begin{array}{l}6 \\
1\end{array}$ & $\begin{array}{l}53 \\
72\end{array}$ \\
\hline Total & & 50 & 23 & 14 & 24 & 7 & 7 & 125 \\
\hline \multicolumn{9}{|c|}{ Enema } \\
\hline $\begin{array}{l}\text { Primiparae } \\
\text { Multiparae }\end{array}$ & $\ldots$ & $\begin{array}{l}14 \\
40\end{array}$ & $\begin{array}{r}8 \\
20\end{array}$ & $\begin{array}{l}11 \\
14\end{array}$ & $\begin{array}{r}12 \\
8\end{array}$ & $\begin{array}{l}6 \\
4\end{array}$ & $\begin{array}{r}10 \\
2\end{array}$ & $\begin{array}{l}61 \\
88\end{array}$ \\
\hline Total & & 54 & 28 & 25 & 20 & 10 & 12 & 149 \\
\hline
\end{tabular}

TABLE III-Degrees of faecal contamination at delivery and sources of positive culture in 14 neonates in untreated and control groups with evidence of infection

\begin{tabular}{|c|c|c|c|c|}
\hline \multirow{2}{*}{$\begin{array}{l}\text { Case } \\
\text { No }\end{array}$} & \multicolumn{2}{|c|}{$\begin{array}{l}\text { Grade of faecal } \\
\text { contamination } \\
\quad(0-3)\end{array}$} & \multirow{2}{*}{$\begin{array}{l}\text { Site of } \\
\text { positive } \\
\text { swab }\end{array}$} & \multirow[t]{2}{*}{ Organisms isolated } \\
\hline & \multicolumn{2}{|c|}{ 1st stage 2 nd stage } & & \\
\hline \multicolumn{5}{|c|}{ No enema } \\
\hline $\begin{array}{l}1 \\
2 \\
3 \\
4 \\
5 \\
6 \\
7\end{array}$ & $\begin{array}{l}0 \\
0 \\
0 \\
0 \\
2 \\
1 \\
0\end{array}$ & $\begin{array}{l}2 \\
3 \\
0 \\
0 \\
1 \\
1 \\
1\end{array}$ & $\begin{array}{l}\text { Eye } \\
\text { Skin } \\
\text { Nose } \\
\text { Nose } \\
\text { Umbilicus } \\
\text { Eye } \\
\text { Eye }\end{array}$ & $\begin{array}{l}\text { Escherichia coli, Streptococcus faecalis } \\
\text { Streptococcus faecalis } \\
\text { Escherichia coli, Streptococcus faecalis } \\
\text { Streptococcus faecalis } \\
\text { Staphylococcus aureus } \\
\text { Staphylococcus epidermidis } \\
\text { Staphylococcus epidermidis }\end{array}$ \\
\hline \multicolumn{5}{|c|}{ Enema } \\
\hline $\begin{array}{r}8 \\
9 \\
10 \\
11 \\
12 \\
13 \\
14\end{array}$ & $\begin{array}{l}0 \\
0 \\
1 \\
0 \\
0 \\
0 \\
0\end{array}$ & $\begin{array}{l}2 \\
1 \\
1 \\
0 \\
0 \\
1 \\
1\end{array}$ & $\begin{array}{l}\text { MSU } \\
\text { Skin } \\
\text { Skin } \\
\text { Eye } \\
\text { Skin } \\
\text { Eye } \\
\text { Eye }\end{array}$ & $\begin{array}{l}\text { Streptococcus faecalis } \\
\text { Coliforms, Proteus } \\
\text { Staphylococcus aureus } \\
\text { Staphylococcus aureus } \\
\text { Staphylococcus epidermidis } \\
\text { Staphylococcus aureus } \\
\text { Staphylococcus aureus }\end{array}$ \\
\hline
\end{tabular}

MSU $=$ Midstream specimen of urine.

\section{Discussion}

Perhaps the most interesting feature of the study was the attitudes of the midwives attending the patients in labour. At the start there was some hostility to the trial, which caused problems in design. During the study, however, the midwives' opinions changed, and the random study was terminated prematurely, when objections were raised to subjecting patients to an enema without good reason.

We found no evidence that enemas were harmful, but they caused distress to a few patients and discomfort to many. The enemas did not reduce the incidence of faecal contamination or infection, and nor was there any evidence of a significant influence on the duration of labour.

Constipation is generally regarded as common in pregnancy, possibly due to a combination of relaxation of smooth muscle and increased absorption of water from the colon. ${ }^{2}$ Levy et al, ${ }^{3}$ however, disagree. In a study of 1000 healthy Israeli women they found that most reported no change. Increased frequency of bowel motion occurred in 344 of the women, and 49 had diarrhoea, mostly in the last trimester. Only 110 reported increasing constipation. Hence the widely held belief that women start labour with a chronically overloaded colon likely to interfere with labour is probably fallacious. Our study suggests that normal physiology will deal with bowel function without aid in most cases.

It may be that the small-volume disposable enema is ineffective and that different results would be obtained with a larger-volume conventional soap-and-water enema. This is, however, more time consuming and unpleasant for the patient; and from our data it could be of only marginal benefit.

It was clear that most of our patients disliked the enema and accepted it only because of the advantages claimed, especially a clean delivery. We found no evidence to support these claims. We therefore suggest that the enema should be reserved for patients who have not had their bowels open in the past 24 hours and who have an obviously loaded rectum palpable at the time of initial pelvic examination. For those women who claim to enjoy the enema, in the absence of a good medical reason, it is dubious if their enema is a legitimate charge on National Health Service time and resources.

It is not easy to challenge a procedure which has been an integral part of obstetric practice for over 300 years. Our non-randomised initial study was necessary to provide evidence that a randomised study was ethical. What we did not expect was the resistance by both patients and midwifery staff to the continuation of the controlled trial. We soon foresaw refusal of an enema by patients or its sly omission by staff, which would have endangered the statistical validity of the whole trial. It therefore seemed prudent to terminate the study.

Though our conclusions are justified by the results, there may be some lingering doubts because of the relatively small numbers studied. Similar trials in other centres could reinforce our conclusion that such rectal assaults on women in labour should be discouraged.

\section{References}

${ }^{1}$ Romney ML. Predelivery shaving: an unjustified assault ? fournal of Obstetrics and Gynaecology 1980;1:33-5.

${ }^{2}$ Hytten FE. The alimentary system. In: Chamberlain G, ed. Clinical physiology in obstetrics. London: Blackwell Scientific, 1980 :ch 5:147-62.

${ }^{3}$ Levy N, Lemberg E, Sharf $M$. Bowel habit in pregnancy. Digestion $1971 ; 4: 216-22$.

(Accepted 27 February 1981)

DUCK's MEAT is so well known to swim on the tops of standing waters, as ponds, pools, and ditches, that it is needless further to describe it.

Cancer claims the herb, and the Moon will be Lady of it; a word is enough to a wise man. It is effectual to help inflammations, and St Anthony's Fire, as also the gout, either applied by itself, or in a poultice with Barley meal. The distilled water by some is highly esteemed against all inward inflammations and pestilent fevers; as also to help the redness of the eyes, and swellings of privities, and of the breasts before they be grown too much. The fresh herb applied to the forehead, eases the pains of the head-ache coming of heat. (Nicholas Culpeper (1616-54) The Complete Herbal, 1850.)

\section{Corrections}

Electric convulsion therapy in depression: a double-blind controlled trial

The dose of atropine as a premedication was wrongly quoted in this paper by Dr Eric D West (31 January, p 355). This should have been $0.8 \mathrm{mg}$, not $80 \mathrm{mg}$ as stated.

Relapse rate and long-term management of plaque psoriasis after treatment with photochemotherapy and dithranol

In this paper by Dr D Vella Briffa and others (21 March, p 937) the appointment of Dr A P Warin should have read "consultant dermatologist and senior lecturer." 